\title{
Porphyroblastic Andalusite zoned microstructures respond to multiple pulse magma emplacements?
}

\author{
Nengsong CHen ${ }^{1}$, Binghan CHen ${ }^{1}$, Tingting YAng ${ }^{1}$ \\ ${ }^{1}$ School of Earth Science, China University of Gesciences, Wuhan \\ 430074, China chennengsong@163.com
}

Relationship of multiple minerals growth in a contact aureole to multiple-pulse magma emplacement of a host pluton remains scarcely reported. The Fangshan Pluton in Western Hills of Beijing is formed by five pulses of emplacement of granitoid magma. Intrusion of the pluton generated a hundred to thousand meters wide contact aureole of progressive biotite-andalusite, almandine-staurolite and sillimanite zones. Emplacement of the first two pulses of small-scale clinopyroxene-bearing monzonite and monzodiorite, which caused formation of a thin baked margin as usual. The fifth pulse of mega-porphyritic monzogranite emplaced SE to NW obliquely upwards and resulted in formation of a crescented blastomylonite belt inside the semi-solidified granitoids of the fourth and adjacent part of the third pulses and cross the contact boundary into the aureole, thus constraining that formation of the aureole occurred during emplacement of the third and fourth pulses. Andalusite porphyroblasts in the almandinestaurolite and sillimanite zones usually developed outwards two sets of zoned microstructures (Figure 1). Each set consists of a inclusions-rich inner zone and a inclusion-free outer zone, suggesting double processes of rapid heating $\rightarrow$ slow annealing, and probably responding to heating and cooling of two pulses of magma emplacement, analogous to the third and fourth pulses of magma emplacement that making up of parts of the Fangshan Pluton, Zhoukoudian, Western Hills of Beijing.

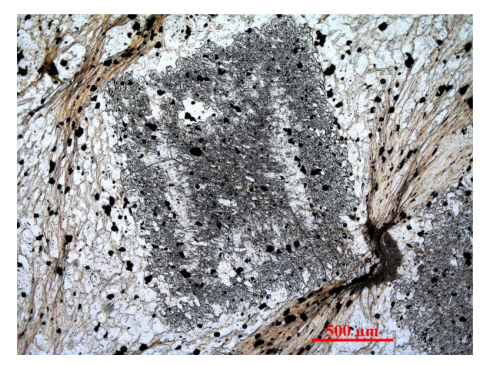

Figure 1. A microphotograph showing zoned microstructures of the porphyroblastic andalusite from the almandine-staurolite and sillimanite zones around the Fangshan Pluton, Beijing.

The study was supported by National Natural Science Foundation of China (NSFC No. 41672060). 